\title{
Collective Rituals in Times of the COVID-19 Quarantine: The Relationship between Collective Applause and Identity Fusion
}

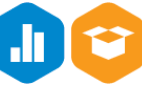 \\ Roberto M. Lobato ${ }^{1}$ (D), Mario Sainz ${ }^{2}$ \\ ${ }^{1}$ Euro-Arab Foundation for Higher Studies, Granada, Spain \\ ${ }^{2}$ Escuela de Psicología, Pontificia Universidad Católica de Chile, Santiago de Chile, Chile
}

Several initiatives are arising to counterbalance the consequences of psychical distance, motivated by COVID-19, by reinforcing social ties. In this project, we focus on analyzing the relationships between participating in collective applause (i.e., a collective ritual), reinforcement of collective/relational ties, identity fusion, and compliance with quarantine norms. We carried out a study during the COVID-19 quarantine $(N=568)$ with people who were legally obliged to stay home. Our results indicate that participating in collective rituals relates to collective and relational ties with in-group members. This, in turn, is associated with the strength of identity fusion and the perception that other in-group members comply with quarantine norms. Thus, under the influence of a common fate that invariably threatens the lives of a large part of the population, participating in collective rituals positively relates to an increase in the sense of belonging and common identity.

Key words: identity fusion, quarantine, rituals, collective applause, social norms, COVID-19

The COVID-19 pandemic has dramatically affected the world population, as the number of infected people and deaths is rapidly increasing (World Health Organization, 2020). Several countries, such as Spain and Italy, advocated legally forcing citizens to stay at home to slow the spread of the virus (EFE, 2020). These lockdown measures have transformed the social life of many individuals. However, several initiatives appear to counterbalance the consequences of psychical distance by promoting activities that reinforce social ties. This is the case of collective applause, a practice carried out in Spain that brings people together at windows or balconies each day at 8:00 pm to acknowledge the collective effort in slowing down the spread of the virus. In the present research, we aimed to analyze the extent to which this collective ritual is linked to the psychosocial impact on people's sense of identification and compliance with social norms during the quarantine.

Correspondence concerning this article should be addressed to Mario Sainz, Escuela de Psicología, Pontificia Universidad Católica de Chile, Santiago de Chile, Chile. E-mail: mario.sainz@uc.cl

All data and supplementary materials are available online at https://osf.io/grj5f/

Received June 1, 2020

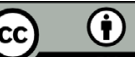




\section{Social Identity during Collective Threats}

Critical situations usually tend to generate social cohesion and strengthen social identity through reinforcing the presence of a common fate among affected people (e.g., Drury, 2018). The common fate operates as a form of comparative fit, enhancing perceptions of within-group similarity and clarifying group boundaries (Turner, 1981), which could motivate different forms of solidarity (Gaertner \& Dovidio, 2012). In this vein, an extreme form of identification that promotes the performance of in-group altruistic actions is identity fusion.

Identity fusion is described as a visceral feeling of oneness with a group in which the personal and social self-merge and the boundaries between both identities become more permeable (Gómez \& Vázquez, 2015b; Swann \& Buhrmester, 2015; Swann, Jetten, Gómez, Whitehouse, \& Bastian, 2012). One of the identity fusion principles that makes it different from other forms of identification is the relational ties principle (Gómez \& Vázquez, 2015a; Swann et al., 2012). According to this principle, people with fused identities have strong personal and social identities and tend to believe that other group members also have them. This ability to recognize personal identities as unique, as well as social, allows people to develop an attraction based on both uniqueness and group membership. This combination of attraction can produce exceptionally strong relational ties. Thus, fusion is marked by a strong allegiance to the group category (collective ties) and, at the same time, to the fellow group members (relational ties); in other words, fused individuals feel strong ties to a category (collective ties: identification with the group category) and to the group members (relational ties: identification with the group members; Gómez et al., 2019; Vázquez, Gómez, \& Swann, 2017).

\section{Collective Rituals Reinforce Identity Fusion}

Collective rituals enhance a sense of belonging to the group and reinforce social identity (Drury \& Reicher, 2009; Khan et al., 2016). In the same way, identity fusion is closely related to engagement in rituals. Some researchers suggest that fusion results from shared ritualistic activities that are emotional, causally opaque, and symbolically charged (Jong, Whitehouse, Kavanagh, \& Lane, 2015; Whitehouse, 2018). Others point out that it is the shared essence (e.g., values) that causes the fusion (Swann et al., 2014). Beyond this debate, there is evidence that participating in collective gatherings increases fusion. For example, it has been proven that involvement in folkloric marches (Páez, Rimé, Basabe, Wlodarczyk, \& Zumeta, 2015; Zumeta, Basabe, Wlodarczyk, Bobowik, \& Páez, 2016), pilgrimages (Lobato \& Sainz, 2019), presidential inaugurations (Kapitány, Kavanagha, Buhrmester, Newson, \& Whitehouse, 2019), martial arts ceremonies (Kavanagh, Jong, McKay, \& Whitehouse, 2018), or even artificial performances (Reddish, Tong, Jong, Lanman, \& Whitehouse, 2016) is related to an increase in identity fusion among those who share the same identity markers.

All these gatherings have something in common: the interaction among individuals. During the mentioned gatherings, individuals involved can interact with each other. In this vein, Lobato and Sainz (2019) found that once a ritual is over, personal contact reinforces identity fusion. They concluded that intragroup contact (Dovidio, Love, Schellhaas, \& Hewstone, 2017) should be related to the maintenance of identity fusion. In fact, as previously mentioned, relational ties (i.e., identification with the group members) are one of the characteristics that distinguish identity fusion from other forms of identification as social identity (Gómez et al., 2019; Vázquez et al., 2017). That is, identity 
fusion and social identity theories differ in the importance given to relational ties (involving attachment to fellow group members) and collective ties (involving allegiance to the group identity). Whereas social identity theory emphasizes the importance of collective ties to the group category (Hogg, 2009), in the identity fusion perspective, both collective and relational ties can be salient and motivating at the same time (Vázquez et al., 2017). This raises the question of whether it is possible to fuse when intragroup contact is limited. In this research, we argue that it is possible through ritual engagement. Thus, we expected that engagement in collective applause and its underlying motivation would strengthen identity fusion through the reinforcement of collective and relational ties.

Finally, there is empirical evidence that individuals with a fused identity tend to engage more frequently in several kinds of actions to protect or defend the entity with which they are fused (e.g., engage in costly sacrifices: Swann et al., 2014; Swann, Gómez, Huici, Morales, \& Hixon, 2010; Swann, Gómez, Seyle, Morales, \& Huici, 2009; or donate money: Buhrmester, Fraser, Lanman, Whitehouse, \& Swann, 2014; Gómez, Morales, Hart, Vázquez, \& Swann, 2011; Swann et al., 2010). Therefore, we also expected that strongly fused individuals would comply with quarantine norms more than weakly fused individuals would. Moreover, strongly fused individuals tend to perceive that other members of the group are also extraordinarily committed to the group; that is, they perceive similarity of their own attitudes to those of other group members (Swann et al., 2009, 2012). Hence, we also expected them to perceive compliance with the norms by in-group members.

\section{The Present Research}

Based on previous insights, in the present research, we sought to answer some questions related to the motivations to engage in collective applause when intragroup contact is limited and its relationships with identity fusion and compliance with the quarantine norms in the context of the COVID-19 pandemic. The lockdown measures imposed to slow the spread of the virus that restricted intragroup contact offered a perfect context to analyze these insights. Specifically, we hypothesized that the practice of collective applause during the quarantine would be related to more social motivations (an exploratory hypothesis; $\mathrm{H} 1$ ) and would promote the increase of collective and relational ties $(\mathrm{H} 2)$, which in turn would favor the appearance of identity fusion (H3) and, lastly, compliance with personal and societal norms (H4). Thus, we explored the mediational role of identity fusion in the relationship between collective applause and compliance with norms (H5). The data and materials of this project can be found online: https://osf.io/gri5f/.

\section{Method}

\section{Participants, Procedure, and Measures}

The final sample was composed of 568 Spanish participants (376 women, $M_{\text {age }}=34.18$, $S D=13.93)$. An Internet survey was distributed through snowball sampling and a university mailing list. Data collection started one week after the beginning of the collective applause (22 March, 2020), and it was open for two weeks. Once participants agreed to volunteer in an online study about the quarantine, they were presented with the questions. A post-hoc sensitivity analysis was conducted using Monte Carlo power analysis for indirect effects (Schoemann, Boulton, \& Short, 2017). Considering the sample size $(N=568)$ and $\alpha=$ .05 , the power reached was .88 . This implies that our sample was enough to detect a small effect size. 


\section{Participation in the Collective Applause}

We included one single item indicator to measure the extent to which people participated in the collective ritual (i.e., an opaque causal action). Participants were asked on how many days during the first week of the quarantine they participated in the collective applause (from 1 to 7 ).

\section{Motivations for Participation in the Collec- tive Applause}

Open questions were included to assess the reasons for applauding, whom the applause was for, and the reasons for not applauding. Participants who applauded during the seven days $(23.7 \%)$ answered questions about their reasons for applauding and the object of the applause; participants who applauded on only a few days $(53.8 \%)$ answered the same questions and also described their reasons for not applauding. Those who did not applaud on any day responded with their reasons for not applauding (22.5\%).

\section{Identity Fusion, Collective and Relational Ties}

Identity fusion was evaluated with the seven-item identity fusion verbal scale developed by Gómez, Brooks, et al. (2011; e.g., "I am strong because of my country"; $\alpha=.90$ ). All responses were measured on a seven-point Likert scale ranging from 0 (Fully disagree) to 6 (Fully agree). We also evaluated collective (two items; e.g., "I feel strong ties to my country"; $r_{\text {spearman-Brown }}=.95$ ) and relational ties (two items; e.g., "I feel strong ties to the members of my country"; $r_{\text {spearman-Brown }}=.95$ ) with the items taken from Vázquez et al. (2017). Given the strong relationship between the three constructs, we carried out a confirmatory factor analysis (CFA) that provided evidence of their independence. The three-factor solution produced acceptable fit $\left(\chi_{(32)}^{2}=487.73, p<.001\right.$, $\mathrm{CFI}=0.91, \mathrm{TLI}=0.88, \mathrm{RMSEA}=0.16, \mathrm{SRMR}=$ $0.06, \mathrm{AIC}=17820.44)$ and fit the data better than the two-factor solutions (fusion and collective ties as one factor and relational ties as another factor: $\Delta \chi^{2}=405.18, p<.001$; relational and collective ties as one factor and fusion as another factor: $\left.\Delta \chi^{2}=349.49, p<.001\right)$ or the one-factor solution $\left(\Delta \chi^{2}=730.65, p<.001\right)$.

\section{Compliance with Norms}

Personal ("To what extent have you followed the quarantine rules?") and perceived societal compliance with the norms ("To what extent do you think most Spaniards have followed the quarantine rules?") were measured with single indicators. Answers ranged from 0 (Not at all) to 100 (Strictly).

Finally, participants provided sociodemographic information such as gender, age, nationality, country of residence, number of household members $(M=2.89, S D=1.30)$, and political orientation (1-Left-wing to 7Right-wing; $M=3.03, S D=1.65)$.

\section{Results}

\section{Motivations to Participate in the Collective Ritual}

First, we categorized the motivations to participate in the collective ritual using inductive content analysis (Elo \& Kyngäs, 2008). We distinguished three themes, each with different categories, which showed high inter-rater reliability: the reasons for applauding $(\kappa=.90)$, the target audience of the applause $(\kappa=.95)$, and the reasons for not applauding $(\kappa=.90)$. Categories were not mutually exclusive, so that each participant could select more than one category in each system; frequencies and 
percentages of each category are presented in Table 1.

Second, we used Student's $t$-test to explore differences in identity fusion as a function of the different motivations to participate in the collective applause. As can be seen in Table 2 , within the reasons to participate, those participants who engaged in the applause to socialize with their neighbors presented higher fusion. When their applause was meant for security personnel, they presented higher identity fusion than those who did not direct their applause to such personnel. Finally, within the reasons for not applauding, participants who did not participate in the collective ritual as a type of consequence of dissenting or claiming pragmatism were more weakly fused than those who did not participate for other reasons, while those with temporal barriers presented higher identity fusion than those who did not claim this reason.
The Interplay between Collective Ritual, Identity Fusion, and Compliance with Norms

Descriptive statistics and correlations for all measures are presented in Table 3. Path analyses were conducted to investigate the relationship of collective applause with personal and societal compliance with norms through identity ties and identity fusion (Hypotheses 2-4). We tested the model with the lavaan package for $\mathrm{R}$ using maximum likelihood estimation procedures (Rosseel, 2012). Because of the high correlation between collective and relational ties, a covariance between the standard errors was added. Results revealed that the hypothesized model fit the data well: $\chi_{(7)}^{2}=33.50, p<.001, \mathrm{CFI}=0.98, \mathrm{TLI}=0.95$, RMSEA $=0.08$, SRMR $=0.05$, AIC $=14481.25$. As shown in Figure 1, participating in the collective applause predicted collective and re-

Table 1 Frequencies and percentages of the motivations to participate in the collective applause

\begin{tabular}{lll}
\hline & \multicolumn{1}{c}{ Frequency (Percentage) } \\
\hline Reasons to participate & Yes: $380(85.8 \%)$ & No: $63(14.2 \%)$ \\
Efforts recognition & Yes: $324(73.1 \%)$ & No: $119(26.9 \%)$ \\
Socialization with neighbors & Yes: $86(19.4 \%)$ & No: $357(80.6 \%)$ \\
Entertainment & & \\
Audience target of the applause & Yes: $132(29.9 \%)$ & No: $310(70.1)$ \\
Individuals in quarantine & Yes: $74(16.7 \%)$ & No: $368(83.3 \%)$ \\
Affected people and families & Yes: $24(5.4 \%)$ & No: $418(94.6 \%)$ \\
Vulnerable people (elderly and children) & Yes: $385(87.1 \%)$ & No: $57(12.9 \%)$ \\
Health personnel (doctor, nurses, etc.) & Yes: $293(66.3 \%)$ & No: $149(33.7 \%)$ \\
Workers providing basic services & Yes: $218(49.3 \%)$ & No: $224(50.7 \%)$ \\
Security forces (police, military, etc.) & & \\
Reasons to not participate & Yes: $142(32.5 \%)$ & No: $295(67.5 \%)$ \\
Temporal barriers (e.g., not having time) & Yes: $105(24.1 \%)$ & No: $330(75.9 \%)$ \\
Physical barriers (e.g., now having windows) & Yes: $111(25.5 \%)$ & No: $324(74.5 \%)$ \\
Dissent with the meaning & Yes: $53(12.2 \%)$ & No: $382(87.8 \%)$ \\
Pragmatism (not finding it useful) & Yes: $42(9.6 \%)$ & No: $394(90.4 \%)$ \\
\hline Isolation & &
\end{tabular}


Table 2 Student's t-analysis between motivations to participate in the collective applause and identity fusion

\begin{tabular}{lccccccc}
\hline & \multicolumn{1}{c}{ Yes } & \multicolumn{1}{c}{ No } & & & \\
& $M$ & $S D$ & $M$ & $S D$ & $t$ & $p$ & $d$ \\
\hline Reasons to participate & & & & & & & \\
$\quad$ Efforts recognition & 3.78 & 1.51 & 3.78 & 1.71 & 0.02 & .984 & - \\
$\quad$ Socialization with neighbors & 3.88 & 1.49 & 3.52 & 1.67 & 2.13 & .034 & .23 \\
$\quad$ Entertainment & 3.81 & 1.56 & 3.78 & 1.54 & 0.16 & .876 & .02 \\
Audience target of the applause & & & & & & & \\
$\quad$ Individuals in quarantine & 3.89 & 1.56 & 3.74 & 1.54 & 0.91 & .365 & .10 \\
$\quad$ Affected people and families & 3.89 & 1.48 & 3.76 & 1.56 & 0.68 & .498 & .09 \\
$\quad$ Vulnerable people (elderly and children) & 3.80 & 1.46 & 3.78 & 1.55 & 0.07 & .946 & .01 \\
$\quad$ Health personnel (doctor, nurses, etc.) & 3.78 & 1.51 & 3.82 & 1.79 & 0.21 & .833 & .02 \\
$\quad$ Workers providing basic services & 3.77 & 1.53 & 3.81 & 1.58 & 0.22 & .827 & .03 \\
$\quad$ Security forces (police, military, etc.) & 4.15 & 1.43 & 3.42 & 1.57 & 5.07 & .000 & .49 \\
Reasons to not participate & & & & & & & \\
$\quad$ Temporal barriers (e.g., not having time) & 3.81 & 1.52 & 3.40 & 1.52 & 2.57 & .010 & .27 \\
$\quad$ Physical barriers (e.g., now having windows) & 3.75 & 1.51 & 3.47 & 1.53 & 1.63 & .105 & .18 \\
$\quad$ Dissent with the meaning & 2.89 & 1.36 & 3.76 & 1.52 & 5.31 & .000 & .60 \\
$\quad$ Pragmatism (not finding it useful) & 3.05 & 1.37 & 3.60 & 1.54 & 2.48 & .014 & .38 \\
Isolation & 3.75 & 1.70 & 3.51 & 1.51 & 0.96 & .337 & .15 \\
\hline
\end{tabular}

lational ties, which predicted identity fusion, which, in turn, predicted societal compliance with norms, but not personal compliance with norms. In addition, we tested three different models. The first was the same model without personal compliance with norms $\left(\chi_{(4)}^{2}=29.09, p<.001, \mathrm{CFI}=0.98, \mathrm{TLI}=0.94\right.$ RMSEA $=0.11$, SRMR $=0.05$, AIC $=10098.80)$, which presented a similar fit $\left(\Delta \chi^{2}=4.41, p=\right.$ .220). The second was the same model with the variables inverted (i.e., collective/relational ties-identity fusion-collective applause-personal/societal compliance with norms; $\chi_{(8)}^{2}=51.6, p<.001, \mathrm{CFI}=0.96, \mathrm{TLI}=0.92$, RMSEA $=0.10$, SRMR $=0.08$, AIC $=17194.99)$ with a worse fit $\left(\Delta \chi^{2}=18.16, p<.001\right)$. In this model, collective applause did not predict personal ( $b=-0.21, p=.529$ ) or societal compliance $(b=0.21, p=.403)$ with norms. Finally, in the third model, societal compliance with norms predicted personal compliance $\left(\chi_{(8)}^{2}=\right.$
33.95, $p<.001, \mathrm{CFI}=0.98, \mathrm{TLI}=0.96, \mathrm{RMSEA}$ $=0.08, \mathrm{SRMR}=0.05, \mathrm{AIC}=14479.70)$, which also presented a similar fit $\left(\Delta \chi^{2}=0.45, p=\right.$ .502). In this case, societal compliance significantly predicted personal compliance with norms $(b=0.17, p<.001)$.

Consequently, we calculate the bootstrapped confidence interval estimates of the indirect effects to test the indirect effect hypothesis (95\% Cl; 10,000 bootstraps; Hayes, 2018; H5). As predicted, the effect of collective applause on societal compliance with norms was mediated by identity fusion $(b=$ $.17, S E=.07 ; 95 \% \mathrm{Cl}=[.05, .31])$. This effect was also mediated by collective $(b=.36$, $S E=.11 ; 95 \% \mathrm{Cl}=[.17, .59])$ and relational ties $(b=.41, S E=.12 ; 95 \% \mathrm{Cl}=[.21, .67])$. Nevertheless, when we considered the ties and identity fusion as sequential mediators, we did not find significant indirect effects through collective ties and identity fusion $(b=$ 


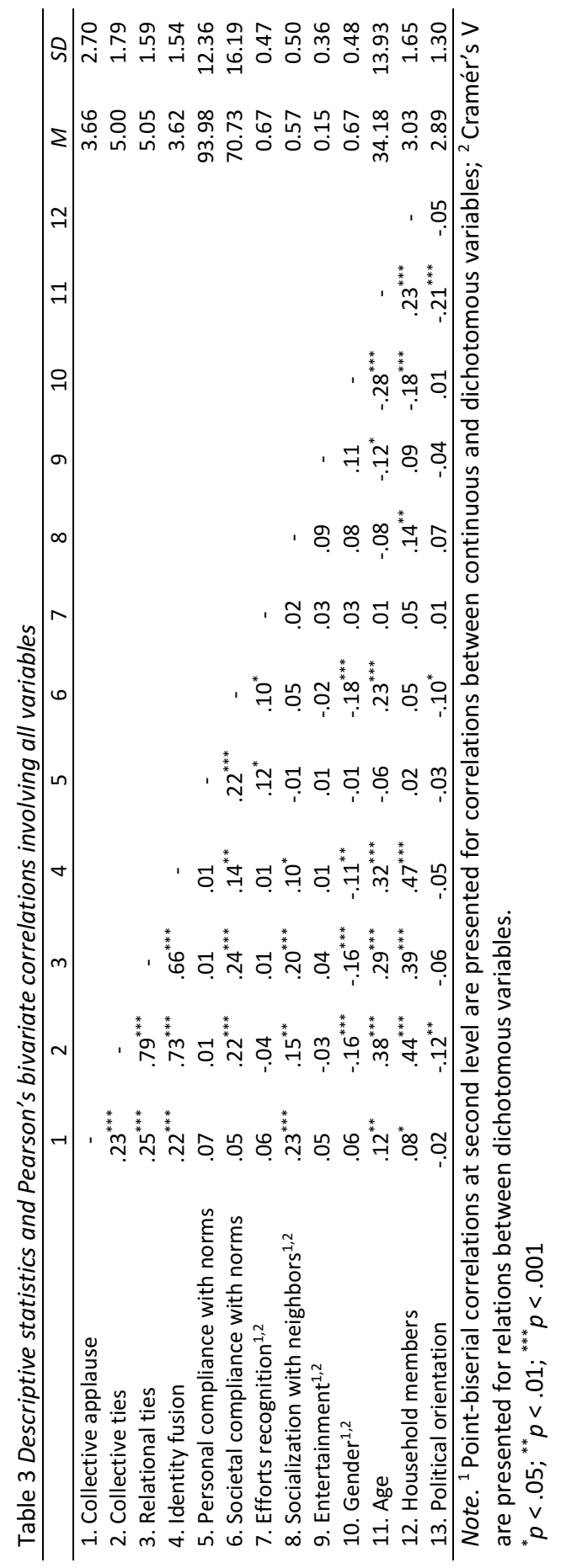




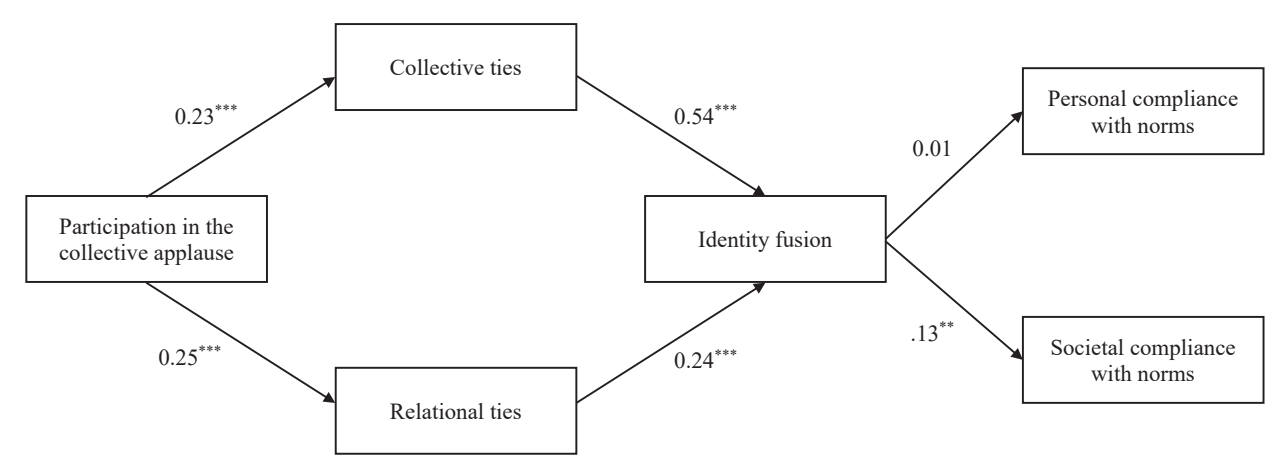

Figure 1 Results from path analysis

Note. Covariance paths and error terms are not shown for clarity; standardized coefficients are presented in the figure; ${ }^{* *} p<.01 ;{ }^{* * *} p<.001$.

$-.06, S E=.06 ; 95 \% \mathrm{Cl}=[-.19, .05])$, nor through relational ties or identity fusion $(b=-.05, S E=$ $.06 ; 95 \% \mathrm{Cl}=[-.17, .05])$. These last results could be determined by multicollinearity. Likewise, the effect of collective applause on personal compliance with norms was mediated sequentially by identity fusion and societal compliance with norms $(b=.27, S E=.09$; $95 \% \mathrm{Cl}=[.10, .44])$. The inclusion of gender, age, household members, and political orientation did not change the main results.

\section{Discussion}

In the present research, we analyzed the relationship among participating in collective rituals, strength of collective/relational ties, reinforcement of identity fusion, and compliance with norms during the quarantine, in a lockdown context. Accordingly, we hypothesized that engagement in collective applause would be related to more social motivations and would predict identity fusion through strengthening collective and relational ties. Identity fusion would predict personal and perceived societal compliance with norms, and it would mediate the relationship between collective applause and compliance with norms. The hypotheses were partially supported.

First, we found that only the motivation to socialize was related to identity fusion. These results are in line with the results of Lobato and Sainz (2019), who found that engaging in opaque actions during a ritual and maintaining contact reinforces identity fusion. On the opposite side, we found that those who dissented the applause meaning and found it unnecessary presented weak fusion. Thus, identity fusion might only be reinforced by rituals when motivations are more social-oriented. Further research is needed to prove this hypothesis.

Second, participation in collective applause predicted identity fusion through collective and relational ties. Engaging in rituals also seems to strengthen relational ties, promoting identity fusion and not just collective ties. Therefore, identity fusion is more likely to be strong through rituals than just social identity (Gómez et al., 2019; Vázquez et al., 2017).

Third, identity fusion did not predict personal compliance with norms, but it predicted 
societal compliance with norms; additionally, identity fusion predicted personal compliance through societal compliance. On the one hand, social desirability could alter the results of personal compliance with norms given the high scores and lack of variability in the participants' responses (ceiling effect). However, it is possible that non-fused members also comply with norms due to other factors such as fear of contagion, sense of responsibility, or the legal obligation to follow the quarantine rules. On the other hand, identity fusion seems to be related to the perception that fused individuals have of other members. Identity fusion might distort the perceptions of the other members in the sense that they are perceived as more willing to sacrifice and follow the in-group norms (Vázquez, López-Rodríguez, Martínez, Atran, \& Gómez, 2020), which could promote trust in fellow members and, at the same time, indicate to the fused individuals the norm that they must follow.

Finally, we found that engaging in rituals goes beyond identity fusion and has consequences on perceived societal compliance with norms. Those who engaged in the collective applause presented higher identity fusion and perceived that a higher percentage of Spaniards were following the quarantine rules. Indeed, relational ties presented a closer relationship to societal compliance with norms, which gives some insights about the power of identity fusion to distort in-group members' perceptions in threat contexts (Vázquez et al., 2020). Most importantly, these gatherings have similar effects even when intragroup contact is limited. Therefore, this research expands the literature regarding collective gatherings and rituals by suggesting that intragroup physical contact and interactions are not necessary for the psychosocial benefits associated with this type of practice to occur.
These results have some implications related to engagement in rituals. Individuals could use rituals to alleviate the effects of isolation and maintain bonds with fellow members, improving their self-esteem (Páez et al., 2015) and promoting prosocial behavior (Buhrmester et al., 2014; Gómez, Morales et al., 2011; Swann et al., 2010). These collective rituals could constitute a coping technique for people in isolation. Furthermore, a worrying number of Muslims become radicalized while in prison (Bianchi, 2018; Trujillo, Jordán, Gutiérrez, \& González- Cabrera, 2009), so the practice of rituals could be a mechanism that helps them fuse their identities with an imaginary umma so they become ready to sacrifice. In the same way, rituals could increase trust in other members. Given that identity fusion has been related to willingness to engage in costly sacrifices, such as fighting and dying for the in-group (Swann et al., 2009, 2010, 2014), lone actors could become fused and realize self-sacrifice acts, expecting others to follow their steps given their trust (Hemmingby \& Bjørgo, 2018). In the context of the COVID-19 pandemic, rituals seem to promote a greater sense of coping and a lowered sense of stress (Khan et al., 2015), as well as physical and mental well-being (Jetten, Haslam, \& Haslam, 2012; Tewari, Khan, Hopkins, Srinivasan, \& Reicher, 2012), thus alleviating the effects of quarantine. Nonetheless, identity fusion could also increase tension with out-group members (e.g., prejudice and discrimination toward individuals who do not follow quarantine norms; Cikara, Bruneau, \& Saxe, 2011; Kteily, Hodson, \& Bruneau, 2016).

It is also important to highlight some limitations to consider when interpreting the results. Due to the rapid spread of the virus, we were only able to collect data once the lockdown was enforced, so we only have a transversal correlational study that limits our conclusions. Thus, the correlational nature of the study does 
not support causality inferences, although the predicted model fit better than the alternative models. Similarly, we only collected data during the second and third weeks of the quarantine, so we are not sure if the effects were the same in the following weeks. Moreover, we did not explore the effects of the collective applause on well-being through identity fusion, so we rely on further research related to rituals and social identity when listing the implications. Therefore, further research is necessary to prove these relationships. Finally, other authors considered different mechanisms through which rituals produce psychological effects on participants, such as collective effervescence (Durkheim, 1912), perceived emotional synchrony (Páez et al., 2015), or episodic memory (Whitehouse \& Landman, 2014), among others. Future studies should test whether these mechanisms are also reinforced when intragroup contact is compromised.

In brief, this research highlights that even during periods of deep threat to our health that forces us into psychical isolation, participation in collective rituals could promote strong ties among individuals and reinforce the sense of union. Therefore, fused individuals could use rituals as a substitute for contact that reinforces relational ties, strengthening their identity and promoting trust in in-group members.

\section{Acknowledgment}

We acknowledge support from the Centre for Social Conflict and Cohesion Studies - COES (ANID/FONDAP/15130009).

This research was funded by Agencia Nacional de Investigación y Desarrollo - ANID - through the program FONDECYT Postdoctorado 2020 [Project number 3200031].

\section{Authors' ORCID}

Roberto M. Lobato

https://orcid.org/0000-0003-4152-7020

\author{
Mario Sainz \\ https://orcid.org/0000-0002-2048-5872
}

\section{References}

Bianchi, S. (2018). Understanding violent escalations in prison beyond radicalisation. Retrieved from https://www.agenformedia.com/sites/agenformedia.com/files/docs/strikes in prison 0.pdf

Buhrmester, M. D., Fraser, W. T., Lanman, J. A., Whitehouse, H., \& Swann, W. B. (2014). When terror hits home: Fused Americans saw Boston bombing victims as "family" and rushed to their aid. Self and Identity, 14, 253-270. https://doi.or $\mathrm{g} / 10.1080 / 15298868.2014 .992465$

Cikara, M., Bruneau, E. G., \& Saxe, R. R. (2011). Us and them: Intergroup failures of empathy. Current Directions in Psychological Science, 20, 149-153. https://doi.org/10.1177/0963721411408713

Dovidio, J. F., Love, A., Schellhaas, F. M. H., \& HewStone, M. (2017). Reducing intergroup bias through intergroup contact: Twenty years of progress and future directions. Group Processes \& Intergroup Relations, 20, 606-620. https:// doi.org/10.1177/1368430217712052

Drury, J. (2018). The role of social identity processes in mass emergency behaviour: An integrative review. European Review of Social Psychology, 29, 38-81. https://doi.org/10.1080/10463283. $\underline{2018.1471948}$

Drury, J., \& Reicher, S. (2009). Collective psychological empowerment as a model of social change: Researching crowds and power. Journal of Social Issues, 65, 707-725. https://doi.org/10.1111/ j.1540-4560.2009.01622.x

Durkheim, E. (1912). Les formes élémentaires de la vie religieuse [The elementary forms of religious life]. Paris, France: Presses universitaires de France.

EFE (2020, March 28). Spain focuses on burdened ICUs as strengthened lockdown enforced. EFE Agency. Retrieved from https://www.efe.com/ efe/english/portada/spain-focuses-on-burdened-icus-as-strengthened-lockdown-enforced/50000260-4207914

Elo, S., \& Kyngäs, H. (2008). The qualitative content analysis process. Journal of Advanced Nursing, 62, 107-115. 
Gaertner, S. L., \& Dovidio, J. F. (2012). The common ingroup identity model. In P. A. M. Van Lange, A. W. Kruglanski, \& E. T. Higgins (Eds.), Handbook of theories of social psychology (Vol. 2, pp. 439457). Thousand Oaks, CA: Sage.

Gómez, Á., Brooks, M. L., Buhrmester, M. D., Vázquez, A., Jetten, J., \& Swann, W. B. (2011). On the nature of identity fusion: Insights into the construct and a new measure. Journal of Personality and Social Psychology, 100, 918-933. https://doi.org/10.1037/a0022642

Gómez, Á., Morales, J. F., Hart, S., Vázquez, A., \& Swann, W. B. (2011). Rejected and excluded forevermore, but even more devoted: Irrevocable ostracism intensifies loyalty to the group among identity-fused persons. Personality and Social Psychology Bulletin, 37, 1574-1586. https://doi. org/10.1177/0146167211424580

Gómez, Á., \& Vázquez, A. (2015a). Personal identity and social identity: Two different processes or a single one? / Identidad personal e identidad social. ¿Dos procesos diferentes o uno solo? Revista de Psicología Social, 30, 468-480. http://dx.doi.org/10.1080/02134748.2015.106 $\underline{5091}$

Gómez, Á., \& Vázquez, A. (2015b). The power of 'feeling one' with a group: Identity fusion and extreme pro-group behaviours / El poder de 'sentirse uno' con un grupo: Fusión de la identidad y conductas progrupales extremas. Revista de Psicología Social, 30, 481-511. https://doi.org/10.1 $\underline{080 / 02134748.2015 .1065089}$

Gómez, Á., Vázquez, A., López-Rodríguez, L., Talaifar, S., Martínez, M., Buhrmester, M. D., \& Swann, W. B. (2019). Why people abandon groups: Degrading relational vs collective ties uniquely impacts identity fusion and identification. Journal of Experimental Social Psychology, 85, 103853. https://doi.org/10.1016/i. jesp.2019.103853

Hayes, A. F. (2018). Introduction to mediation, moderation, and conditional process analysis (2nd ed.). New York, NY: The Guilford Press.

Hemmingby, C., \& Bjørgo, T. (2018). Terrorist target selection: The case of Anders Behring Breivik. Perspectives on Terrorism, 12, 164-176.

Hogg, M. A. (2009). Managing self-uncertainty through group identification. Psychological Inquiry, 20, 221-224.
Jetten, J., Haslam, C., \& Haslam, S. A. (Eds.). (2012). The social cure: Identity, health and well-being. Hove, UK: Psychology Press.

Jong, J., Whitehouse, H., Kavanagh, C., \& Lane, J. (2015). Shared negative experiences lead to identity fusion via personal reflection. PLOS ONE, 10, e0145611. https://doi.org/10.1371/journal. pone. 0145611

Kapitány, R., Kavanagh, C., Buhrmester, M. D., Newson, M., \& Whitehouse, H. (2019). Ritual, identity fusion, and the inauguration of president Trump: A pseudo-experiment of ritual modes theory. Self and Identity, 19(3), 293-323. https:// doi.org/10.1080/15298868.2019.1578686

Kavanagh, C. M., Jong, J., McKay, R., \& Whitehouse, H. (2019). Positive experiences of high arousal martial arts rituals are linked to identity fusion and costly pro-group actions. European Journal of Social Psychology, 49, 461-481. https://doi. org/10.1002/ejsp.2514

Khan, S. S., Hopkins, N., Reicher, S., Tewari, S., Srinivasan, N., \& Stevenson, C. (2015). Shared identity predicts enhanced health at a mass gathering. Group Processes \& Intergroup Relations, 18, 504522. https://doi.org/10.1177/1368430214556703 Khan, S. S., Hopkins, N., Reicher, S., Tewari, S., Srinivasan, N., \& Stevenson, C. (2016). How collective participation impacts social identity: A longitudinal study from India. Political Psychology, 37, 309-325. https://doi.org/10.1111/pops.12260

Kteily, N., Hodson, G., \& Bruneau, E. (2016). They see us as less than human: Metadehumanization predicts intergroup conflict via reciprocal dehumanization. Journal of Personality and Social Psychology, 110, 343-370. https://doi. org/10.1037/pspa0000044

Lobato, R. M., \& Sainz, M. (2019). On the way to fusion through the pilgrims' route: Factors that maintain identity fusion in collective rituals. Group Processes \& Intergroup Relations. https:// doi.org/10.1177/1368430219849690

Páez, D., Rimé, B., Basabe, N., Wlodarczyk, A., \& Zumeta, L. (2015). Psychosocial effects of perceived emotional synchrony in collective gatherings. Journal of Personality and Social Psychology, 108, 711-729. https://doi.org/10.1037/pspi0000014 Reddish, P., Tong, E. M. W., Jong, J., Lanman, J. A., \& Whitehouse, H. (2016). Collective synchrony increases prosociality towards non-perform- 
ers and outgroup members. British Journal of Social Psychology, 55, 722-738. https://doi. org/10.1111/bjso.12165

Rosseel, Y. (2012). lavaan: An R package for structural equation modelling. Journal of Statistical Software, 48, 97589. https://10.18637/jss.v048.i02

Schoemann, A. M., Boulton, A. J., \& Short, S. D. (2017). Determining power and sample size for simple and complex mediation models. Social Psychological and Personality Science, 8, 379-386. https://doi.org/10.1177/1948550617715068

Swann, W. B., \&Buhrmester, M.D. (2015). Identityfusion. Current Directions in Psychological Science, 24, 5257. https://doi.org/10.1177/0963721414551363

Swann, W. B., Buhrmester, M. D., Gómez, Á., Jetten, J., Bastian, B., Vázquez, A., ... \& Zhang, A. (2014). What makes a group worth dying for? Identity fusion fosters perception of familial ties, promoting self-sacrifice. Journal of Personality and Social Psychology, 106, 912-926. https:// doi.org/10.1037/a0036089

Swann, W. B., Gómez, Á., Huici, C., Morales, J. F., \& Hixon, J. G. (2010). Identity fusion and self-sacrifice: Arousal as a catalyst of pro-group fighting, dying, and helping behavior. Journal of Personality and Social Psychology, 99, 824-841. https:// doi.org/10.1037/a0020014

Swann, W. B., Gómez, Á., Seyle, D. C., Morales, J. F., \& Huici, C. (2009). Identity fusion: The interplay of personal and social identities in extreme group behavior. Journal of Personality and Social Psychology, 96, 995-1011. https://doi. org/10.1037/a0013668

Swann, W. B., Jetten, J., Gómez, Á., Whitehouse, H., \& Bastian, B. (2012). When group membership gets personal: A theory of identity fusion. Psychological Review, 119, 441-456. https://doi. org/10.1037/a0028589

Tewari, S., Khan, S., Hopkins, N., Srinivasan, N., \& Reicher, S. (2012). Participation in mass gath- erings can benefit well-being: Longitudinal and control data from a North Indian Hindu pilgrimage event. PloS ONE, 7, e47291. https://doi. org/10.1371/journal.pone.0047291

Trujillo, H., Jordán, J., Gutiérrez, J., \& GonzálezCabrera, J. (2009). Radicalization in prisons? Field research in 25 Spanish prisons. Terrorism and Political Violence, 21, 558-579. https://doi. org/10.1080/09546550903153134

Turner, J. C. (1981). The experimental social psychology of intergroup behaviour. In J. C. Turner \& H. Giles (Eds.), Intergroup behaviour (pp. 66101). Oxford: Blackwell.

Vázquez, A., Gómez, Á., \& Swann, W. B. (2017). Do historic threats to the group diminish identity fusion and its correlates? Self and Identity, 16, 480-503. https://doi.org/10.1080/15298868.20 $\underline{16.1272485}$

Vázquez, A., López-Rodríguez, L., Martínez, M., Atran, S., \& Gómez, Á. (2020). Threat enhances aggressive inclinations among devoted actors via increase in their relative physical formidability. Personality and Social Psychology Bulletin. https://doi.org/10.1177/0146167220907466

Whitehouse, H. (2018). Dying for the group: Towards a general theory of extreme self-sacrifice. Behavioral and Brain Sciences, 41, e192. https:// doi.org/10.1017/S0140525X18000249

Whitehouse, H., \& Lanman, J. A. (2014). The ties that bind us: Ritual, fusion, and identification. Current Anthropology, 55(6), 674-695. https:// doi.org/10.1086/678698

World Health Organization (2020). Coronavirus disease (COVID-19) pandemic. Retrieved from https://www.who.int/emergencies/diseases/ novel-coronavirus-2019

Zumeta, L., Basabe, N., Wlodarczyk, A., Bobowik, M., \& Páez, D. (2016). Shared flow and positive collective gatherings. Anales de Psicología, 32, 717-727. https://doi.org/10.6018/analesps.32.3.261651 